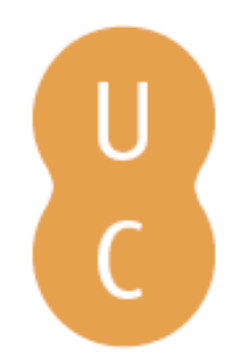

\title{
nommalina
}

\section{O limite da democracia: o problema da tirania do ponto de vista psicológico em Heródoto e no Édipo Rei de Sófocles}

\author{
Autor(es): $\quad$ Lopes, Daniel Rossi Nunes \\ Publicado por: Imprensa da Universidade de Coimbra \\ URL \\ persistente: URI:http://hdl.handle.net/10316.2/45154 \\ DOI: $\quad$ DOI:https://doi.org/10.14195/978-989-26-1679-7_12 \\ Accessed : $\quad$ 26-Apr-2023 05:12:27
}

A navegação consulta e descarregamento dos títulos inseridos nas Bibliotecas Digitais UC Digitalis, UC Pombalina e UC Impactum, pressupõem a aceitação plena e sem reservas dos Termos e Condições de Uso destas Bibliotecas Digitais, disponíveis em https://digitalis.uc.pt/pt-pt/termos.

Conforme exposto nos referidos Termos e Condições de Uso, o descarregamento de títulos de acesso restrito requer uma licença válida de autorização devendo o utilizador aceder ao(s) documento(s) a partir de um endereço de IP da instituição detentora da supramencionada licença.

Ao utilizador é apenas permitido o descarregamento para uso pessoal, pelo que o emprego do(s) título(s) descarregado(s) para outro fim, designadamente comercial, carece de autorização do respetivo autor ou editor da obra.

Na medida em que todas as obras da UC Digitalis se encontram protegidas pelo Código do Direito de Autor e Direitos Conexos e demais legislação aplicável, toda a cópia, parcial ou total, deste documento, nos casos em que é legalmente admitida, deverá conter ou fazer-se acompanhar por este aviso.

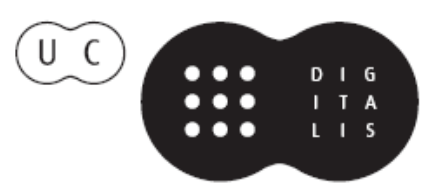



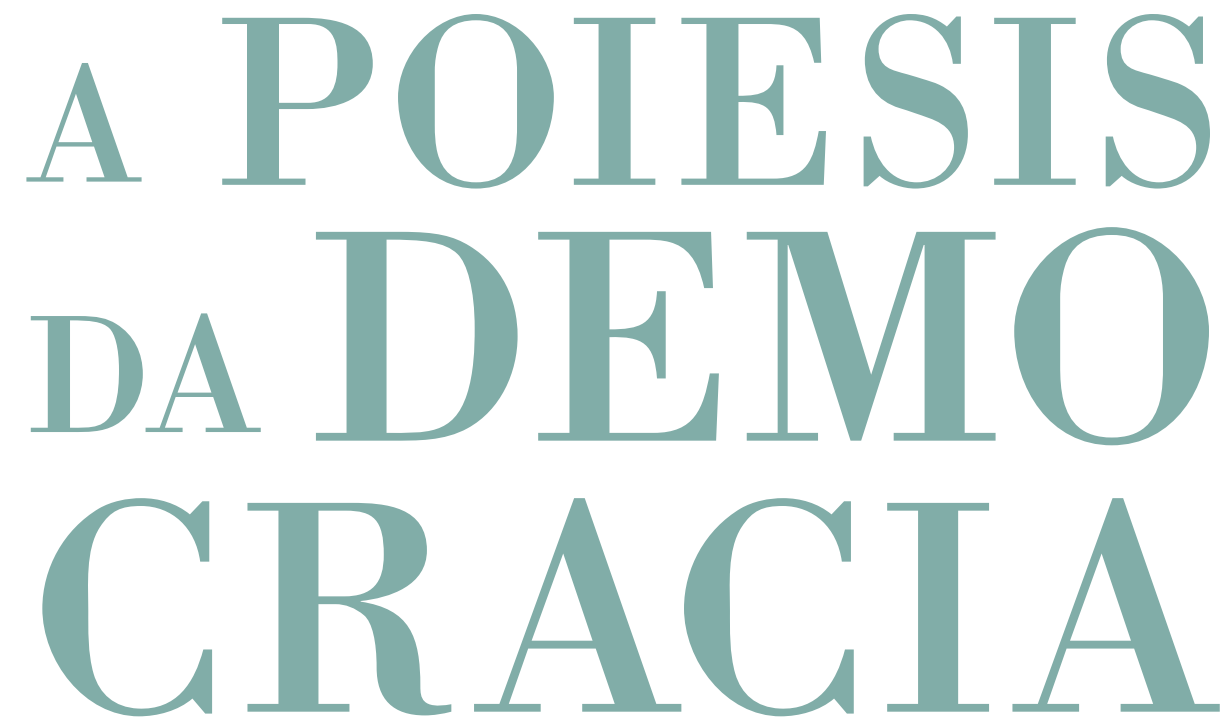

G

Breno Battistin Sebastiani, Delfim Leão,

Lugia Sano, Martinho Soares, Christian Werner

\section{CoimbraCompanions}




\section{O limite da democracia:}

O PROBLEMA DA TIRANIA DO PONTO DE VISTA PSICOLÓgICO EM HERÓdOTO E NO ÉDIPO REI DE SÓFOCLES

\section{THE LIMIT OF DEMOCRACY:}

THE PROBLEM OF TYRANNY FROM THE PSYCHOLOGICAL STANDPOINT IN HERODOTUS AND SOPHOClES' OEDIPUS REX

Daniel Rossi Nunes Lopes

Universidade de São Paulo

ORCID | 0000-0001-9818-8977 


\section{Resumo}

Um dos tópicos principais do pensamento político ateniense dos sécs. V e IV a.C. é o problema da gênese da tirania no seio da democracia, cujos exemplos históricos mais relevantes foram o Governo dos Quatrocentos em 411 a.C. durante a Guerra do Peloponeso, e o governo despótico dos Trinta em 404 a.C. por força de Esparta após a derrota de Atenas. O propósito de nosso capítulo, no entanto, não é abordar o problema do ponto de vista histórico a fim de compreender as circunstâncias particulares, as condições materiais e as motivações políticas que possibilitaram tais experiências autocráticas, ainda que efêmeras, na polis democrática. O que pretendemos examinar, em especial, é um aspecto fundamental da reflexão ético-política a respeito da figura do tirano em textos supérstites do séc. V a.C.: a saber, a sua constituição psicológica. Para tal, nosso recorte consistirá no exame do "Debate Constitucional na Corte Persa" em Heródoto (3.80-82), e do segundo estásimo do Édipo Rei, de Sófocles (v. 863-910), a fim de discutir o fundamento psicológico do problema político representado pela figura do tirano na democracia.

\section{Palavras-chave}

Heródoto, Sófocles, tirania, psicologia 


\section{Abstract}

One central issue of Athenian political thought from the 5th and 4th centuries $\mathrm{BC}$ is concerned with the rise of tyranny from democracy, whose most relevant historical examples were the Government of the Four Hundred in 411 during the Peloponnesian War, and the despotic regime of the Thirty in 404 under Sparta's influence after the Athenian defeat. The aim of this chapter, however, is not to approach the problem from a historical standpoint in order to grasp the particular circumstances, material conditions and political motivations that enabled such autocratic experiences, albeit ephemeral, in a democratic polis. What we intend to examine is rather an essential aspect of the ethical and political reflection on the figure of the tyrant in remaining texts from the 5th century BC: its psychological constitution. To this end, we will focus our attention on examining the Constitutional Debate in the Persian Court in Herodotus (3.80-82), and the second stasimon of Sophocles' Oedipus Rex (v. 863-910) in order to discuss the psychological background of the political problem represented by the figure of the tyrant within democracy.

\section{Keywords}

Herodotus, Sophocles, tyranny. Psychology 


\section{1 - INTRODUÇÃO ${ }^{1}$}

A tirania engendra a hybris? Ou, inversamente, é a bybris que engendra o tirano? Essa célebre controvérsia em torno do verso 873 do Édipo Rei de Sófocles (doravante, OR) sintetiza, em poucas palavras, o problema de natureza política a ser abordado neste capítulo: (a) são as condições políticas propiciadas pelo regime autocrático que dão vazão ao comportamento insolente e desregrado de seu governante? Ou, antes, (b) é um determinado tipo de comportamento, designado genericamente por bybris, que dá origem ao indivíduo tirânico? Quando pensamos nos Livros VIII e IX da República de Platão, por exemplo, não encontraríamos uma resposta unívoca para essa questão: a análise do processo de corrupção das quatro constituições políticas inferiores (i.e. timocracia, oligarquia, democracia e tirania) é acompanhada, passo a passo, pela investigação do movimento correlato de degeneração psicológica dos indivíduos semelhantes a tais regimes políticos, conforme o princípio analógico entre cidade e indivíduo vigente na obra. Nesse sentido, do ponto de vista político, a tirania propicia ao indivíduo dotado de poder político agir irrestritamente conforme os seus próprios desejos e interesses, ao passo que, do ponto de vista do indivíduo, é uma determinada constituição psicológica que dá origem ao tirano, cujas ações seriam manifestações externas dessa disposição interna peculiar que o distingue dos demais homens.

1 A tradução das passagens do Édipo Rei, de Sófocles (a partir da edição de H. LloydJones e N. G. Wilson: Oxford, 1992), e das Memoráveis, de Xenofonte (a partir da edição de E. C. Marchant: Oxford, 1971), são de minha autoria. A tradução das passagens do Livro III, de Heródoto, é de Fátima Silva e Cristina Abranches (Lisboa: Edições 70, 1997), e as do Livro V, de Fátima Silva e Carmen Leal Soares (Lisboa: Edições 70, 2007), com pequenas alterações pontuais na escolha lexical para se conformar à minha argumentação. 
Todavia, Platão não será o foco deste capítulo, mas tão somente o ponto de partida para a discussão sobre um tema que está intimamente associado não apenas ao pensamento grego sobre a democracia, mas à própria constituição da democracia enquanto regime político, especialmente em Atenas - a saber, o problema da gênese do tirano no seio da democracia. A caracterização do demagogo Cléon sob a máscara da personagem Paflagônio na comédia Os Cavaleiros de Aristófanes (424 a.C.), bem como a célebre proposição de Tucídides sobre Péricles no Livro II ("em nome era democracia, mas na prática era o governo do primeiro dos homens", 2. 65. 10²) apontam de diferentes maneiras para o mesmo problema intrínseco à experiência democrática: o perigo da ascensão de um indivíduo poderoso (ou de um pequeno grupo de indivíduos) sobre o restante da comunidade civil, colocando em xeque o princípio de igualdade que fundamenta o regime democrático $^{3}$. Do ponto de vista histórico, o Governo dos Quatrocentos em 411 a.C. durante a Guerra do Peloponeso e a instituição do governo despótico dos Trinta em 404 a.C. por força de Esparta após a derrota de Atenas são os exemplos paradigmáticos de crise e ruptura da ordem democrática que culminaram em dissensão civil e em graves consequências para a cidade. Desde a sua constituição, a democracia ateniense criou leis para proteger a si mesma e punir aqueles indivíduos que conspirassem contra ela (leis que legitimavam inclusive o assassinato de supostos conspiradores $)^{4}$. Em Tucídides, são inúmeras as referências que evidenciam uma preocupação geral para com esse tipo de conluio contra as instituições democráticas, perpetrado, em diferentes circunstâncias históricas, por certos indivíduos e/ou grupo de indivíduos em vista de interesses particulares 5 . Portanto,

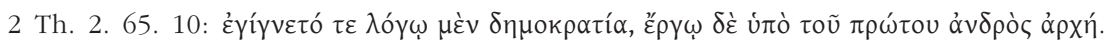

3 Ver Heródoto 5. 92. 1. 1; Tucídides 2. 37, 3. 82. 8; Isócrates, Panatenaico 178; Platão, Menêxeno 239a.

4 Cf. Decreto de Demofante contra a tirania de 410 a.C. (In: Andócides, Sobre os Mistérios 96-98), instituído depois da experiência de destituição da democracia pelo Governo dos Quatrocentos em 411 a.C.

5 Tucídides relata, por exemplo, que, durante a batalha de Tanagra em 458/7 a.C., alguns atenienses negociaram em segredo com os espartanos na Boécia com o intuito de destituir a democracia, ao passo que os atenienses atacaram os espartanos, em parte, porque suspeitavam de um conluio contra a democracia (1. 107). Ver também Tucídides 2. 13, 3. 43, 6. 53. Sobre o assunto, ver Knox 2002: 63-64. 
quando pensamos em democracia grega, inevitavelmente somos levados a refletir também sobre seus próprios limites, e a tirania aparece aqui como a forma mais perfeita de negação do princípio democrático de organização política e social.

A Platão atribui-se a inovação, dentro da história do pensamento ético-político grego, de tratar a tirania não como uma questão simplesmente de natureza política, mas também, e sobretudo, como uma problema de ordem psicológica, de formação de uma certa disposição da alma do indivíduo tirânico, que, em certa medida, antecederia e transcenderia a própria esfera política $^{6}$. Meu intuito neste capítulo, portanto, é tentar verificar, em textos supérstites do séc. V a.C., em que medida já não encontramos ali essa perspectiva psicologizante, por assim dizer, da política ${ }^{7}$, quando o indivíduo tirânico e/ou a tirania estão sob enfoque. Para tal fim, o recorte proposto para a discussão consiste basicamente em dois excertos de duas obras exaustivamente exploradas pela literatura crítica moderna: o Debate Constitucional na Corte Persa em Heródoto (3.80-82), e o segundo estásimo da tragédia OR de Sófocles (v. 863-910).

\section{2 - HERÓdoto}

O Debate Constitucional narrado por Heródoto no Livro III das Histórias (3. 80-82) aparece em um momento crucial da narrativa sobre a história do império persa, na medida em que sua conclusão resultou na ascensão de Dario ao trono persa em 522/1 a.C. ${ }^{8}$ Muito se discutiu no séc. XX a respeito

6 Giorgini 2005: 437: "As condições políticas farão, pois, que os homens de alma tirânica se tornem efetivamente tiranos no sentido político ou menos. Essa é uma outra, significativa, inovação platônica: a tirania é uma condição da alma, que se revela também nos pequenos criminosos e malfeitores, não somente no tirano político. [...] O homem verdadeiramente tirânico é quem faz desperto, na prática, o que os outros sonham somente nos próprios sonhos selvagens, aqueles que nascem do "sono da razão"; o homem tirânico no máximo grau é aquele que, além de ter uma alma tirânica, se encontra à frente de uma cidade". Ver também Schofield 2006: 252.

7 Ver Platão, Fédon 66c; República IX 586a-b.

8 A história do Déjoces, fundador do império medo (1. 96-103), o Debate Constitucional na Corte Persa (3. 80-82) e o discurso do coríntio Socles (5.92) constituem as três passagens 
da plausibilidade desse episódio narrado pelo historiador, ou da suposta influência dos "sofistas" (Protágoras, Hípias, Antifonte, Pródico) sobre ele, tendo em vista o teor político da discussão concernente à melhor constituição política para os homens, que remete diretamente ao tipo de discussão empreendida no ambiente intelectual ateniense ${ }^{9}$. O episódio consiste em três discursos sucessivos proferidos por três membros da corte persa (Otanes, Megabizo e Dario), que defendem, respectivamente, a democracia, a oligarquia e a monarquia ${ }^{10}$ como o melhor regime político a ser adotado pelos persas após a supressão do poder ilegítimo de pseudo-Esmérdis, o mago. Meu interesse nesse episódio, no entanto, deve-se antes a dois fatores peculiares que estão diretamente relacionados ao tema deste capítulo: (a) em primeiro lugar, é o primeiro excerto da literatura grega supérstite em que encontramos uma tentativa teórica de distinguir três regimes políticos (basicamente, poder de um único indivíduo, poder de poucos, poder de muitos, cf. 3. 82. 1), constituindo ponto de partida para o desdobramento de teorias políticas em autores do séc. IV a.C., tais como Platão, Aristóteles, Xenofonte e Isócrates, em que essa tripartição genérica é refinada, expandida e modificada11. (b) E em segundo lugar, é o episódio em que o problema da gênese de um regime autocrático no seio da democracia é claramente articulado, encontrando ecos posteriormente na genealogia degenerativa dos regimes políticos desenvolvida por Platão nos Livros VIII e IX da República. Isso aparece no terceiro discurso proferido por Dario em defesa da monarquia:

[...] Ora, na hipótese inversa, quando é o povo [demos] quem governa, é impossível não haver iniquidades [kakotes]; e quando a iniquidade realmente nasce numa sociedade, não são inimizades que nascem entre os maus, mas sim profundas e temíveis amizades, pois os que agem mal contra o Estado

mais relevantes sobre a tirania e natureza do poder autocrático em Heródoto (Dewald 2003: 27; Dewald 2007: 86; Raaflaub 2002).

9 Asheri 2007: 471-472; Evan 1981; Raaflaub 2002: 161.

10 À "democracia" Heródoto se refere de diferentes formas: isonomia (3. 80. 6), isokratia (5. 92. 1. 1), demos (3. 82. 1), plethos (3. 80. 6; 3. 82. 1).

11 Asheri 2007: 471; Dewald 2002: 25. 
fazem-no pela conspiração. E isso vai acontecendo, até que alguém se ponha à frente do povo [demos] para o defender e os faça parar. A partir de então, esse homem é admirado pelo povo [demos] e, graças a essa admiração, torna-se monarca [mounarchos] - o que evidencia também que a monarquia [mounarchia] é a melhor alternativa. (3. 82. 4)

A proposta de Dario pela manutenção do regime autocrático acaba prevalecendo sobre as tentativas de Otanes e Megabizo de defenderem a democracia e a oligarquia, respectivamente, como a melhor constituição política a ser adotada pelas persas depois da morte de Cambises, o monarca legítimo, e da supressão do golpe perpetrado por Esmérdis, o mago. Mas é no primeiro discurso proferido por Otanes em louvor à democracia que o problema em torno da figura do governante autocrata aparece de modo mais saliente:

A mim, parece-me bem que um só homem deixe de ser o senhor absoluto [mounarchos] de todos nós, pois isso nem é agradável, nem bom. E, de fato, todos aqui presentes não só viram a que ponto chegaram os excessos [bybris] de Cambises, como agora acabaram de testemunhar os excessos [bybris] do mago. Como é que alguma vez poderia a monarquia [mounarchia] ser uma instituição bem organizada, se lhe é permitido fazer o que quiser, sem prestar contas? E penso que porventura até o melhor dos homens, com todo esse poder, ficaria fora dos limites do seu juízo habitual. Gera-se um excesso de orgulho [hybris] pelos bens de que se dispõe e cresce a inveja [phthonos], própria da natureza do homem desde que ele existe. Tendo estas duas características, o rei possui todas as más qualidades [kakotes] que pode haver: farta-se de praticar atos insensatos, uns por já ter cometidos excessos [bybris] até a saciedade, outros por inveja [phthonos]. De fato, um homem dado à tirania [tyrannos] não devia conhecer a inveja [aphthonos], uma vez que tem todos os bens, mas é precisamente o contrário que grassa nas suas relações com os cidadãos [...]. E falta ainda o aspecto mais importante, que vou agora referir: ele não só adultera os costumes dos antepassados, como também violenta as mulheres e até condena à morte sem prévio julgamento. $(3.80 .2-5)$ 
(i) O primeiro ponto que gostaria de observar concerne ao vocabulário empregado por Heródoto para se referir ao governo de um só indivíduo: ele parece empregar indistintamente os termos mounarchos e tyrannos, mas uma análise mais cuidadosa do texto mostra que, ao menos no Debate Constitucional, a distinção entre eles é relevante. Segundo Parker 1998, embora o historiador não distinga no mais das vezes mounarchos, basileus e tyrannos, o termo tyrannos é usado marcadamente, em certas ocasiões específicas, para conotar de modo pejorativo um governante autocrático que, ou (a) usurpou o poder, ou (b) o emprega despoticamente (como, por exemplo, em 5. 92) ${ }^{12}$. Esse uso marcado é patente nesse episódio da história persa, visto que Megabizo, o orador que defenderá a oligarquia e condenará tanto a democracia quanto a monarquia/tirania, emprega apenas tyrannos e tyrannia para se referir pejorativamente ao governo autocrático abusivo e insolente ${ }^{13}$, ao passo que Dario, o defensor da monarquia, utiliza apenas mounarchos e mounarchia em seu elogio a ela (3. 82. 4); no discurso de Otanes (3. 80. 2-5), por sua vez, o termo mounarchos é empregado para designar o governante, num primeiro estágio, antes de incidir em bybris, ao passo que tyrannos é usado para qualificá-lo, num segundo estágio, depois de cometer os atos excessivos que o caracterizariam agora como "tirano", e não mais como "monarca"14. Por conseguinte, ao menos no Debate Constitucional, já podemos detectar uma distinção clara entre monarquia ou realeza, de um lado, e tirania, de outro, que será um lugar-comum do pensamento político grego do séc IV a.C., como podemos ver, de modo paradigmático, nesta passagem das Memoráveis de Xenofonte:

12 Parker 1998: 162, 164. Ver também Dewald 2003: 31-33, 40-41.

13 Heródoto, 3. 81. 1-2: "Em relação a tudo quanto disse Otanes no sentido de se acabar com a tirania [tyrannida], façam-se minhas também as suas palavras. Mas, quando ele exortou a transferir o poder para o povo, andou longe da perspectiva mais correcta. Com efeito, nada há de mais insensato do que uma multidão inútil, nada há de mais insolente [bybristoteron]. E decerto fugirem os cidadãos à insolência de um tirano [tyrannou bybrin], para virem a cair na insolência [bybrin] de um povo descomedido, isso não é, de modo algum, tolerável. É que, se o primeiro dos dois, o tirano, faz alguma coisa, fá-la com plena consciência do que está a fazer; enquanto o outro, o povo, nada pode realmente saber.'

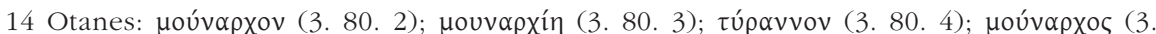

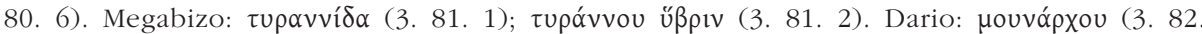

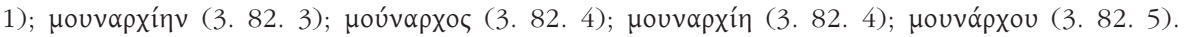


Sócrates considerava tanto a realeza [basileia] quanto a tirania [tyrannis] duas formas de poder, mas admitia diferenças entre elas: considerava a realeza [basileia] o poder aceito voluntariamente pelos homens e conforme as leis da cidade, enquanto a tirania [tyrannis], o poder contra a vontade dos homens e desprovido de leis, mas conforme os desejos do governante. E onde os governantes são escolhidos entre os que cumprem as leis, essa constituição política é a aristocracia; onde eles são escolhidos conforme o censo dos bens, é a plutocracia; e onde eles são escolhidos entre todos os homens, é a democracia. (4.6.12)

Embora essa distinção apareça bem estabelecida no Debate Constitucional, ela não vale como regra para todas as demais ocorrências de tyrannos e tyrannis na obra de Heródoto. Segundo Parker, o sentido negativo desses termos, tal como entendemos hoje quando falamos de um tirano ou de uma tirania, só se sedimenta, de fato, no séc. IV a.C., no âmbito do pensamento político ateniense, ainda que, já na obra de Tucídides, o termo tyrannos seja empregado marcadamente para designar os soberanos das cidades helênicas, que hoje denominaríamos "tiranos"15. Tucídides reserva o termo basileus, por outro lado, para se referir aos governantes mitológicos da Hélade, aos de Esparta, aos da Tessália, e a todos os soberanos dos povos bárbaros, tais como os persas e os líbios ${ }^{16}$. Poderíamos dizer, em suma, que o termo tyrannos até o séc. V a.C. designa em geral o "monarca", e não necessariamente um governante perverso, ainda que haja certas ocorrências na literatura supérstite em que ele é empregado de maneira pejorativa para se referir ao autocrata usurpador ou opressor ${ }^{17}$.

15 i.e., os tiranos de Atenas (ex. Th. 1. 20. 2; 2. 15. 5; 3. 104. 1; 6. 53. 3; 6. 54), de Samos (ex. Th. 1. 13. 6; 3. 104. 2), de Siracusa (ex. Th. 1. 14. 2 Sicília em geral; 6. 4. 2; 6. 94. 1), de Gela (ex. Th. 6. 5. 3), de Régio (ex. Th. 6. 4. 6), de Mégara (Th. 1. 126. 3), de Lâmpsaco (Th. 6. 59. 3), de Astaco na Acarnânia (Th. 2. 30. 1).

16 Parker 1998: 164: "Tucídides é então o primeiro autor que evidencia um conceito claro e consistente de 'tirania' em oposição à realeza, que discerniu claramente um grupo definido de governantes 'tiranos'. Nós hoje seguimos em grande medida a classificação de Tucídides; e a classificação de Tucídides prevaleceu no mundo antigo também.”

17 Tais ocorrências seriam as seguintes, segundo o levantamento de Carey 1986: 176: Heródoto 5. 92. 1; Aristófanes, Vespas 488-ss.; Aristófanes, fr. 110. 2 PCG; Eurípides, As 
(ii) Em segundo lugar, nesse discurso de Otanes, Heródoto articula uma tese segundo a qual o poder absoluto (mounarchie, 3. 80. 2), na medida em que possibilita ao soberano "fazer o que bem quiser sem restrição" (3. 80. 3), condiciona, de um lado, um comportamento excessivo (bybris) devido à ambição pelos bens a que tem acesso, e, de outro, uma inveja (phthonos) aos homens excelentes, passando a se cercar dos piores cidadãos (3. 80. $3)^{18}$. O termo central da reflexão de Heródoto sobre a natureza da tirania é sem dúvida hybris, que tem uma conotação intrinsecamente pejorativa. Hybris pode ser definida, em termos gerais, como: "atitude mental e padrões de comportamento induzidos pela prosperidade material, pelo poder ou pela superioridade física; auto-afirmação inescrupulosa, anti-social e irreligiosa em detrimento dos direitos ou sentimentos dos outros; o excesso é sua essência" (Carey 1986: 176) ${ }^{19}$. Como veremos na análise do segundo estásimo do OR de Sófocles (v. 863-910), em que hybris também aparece como

Fenícias 549; Eurípides, As Suplicantes 429; Eurípides, Medeia 348. Carey 1986: 176 observa que há um uso negativo bastante peculiar, baseado na natureza inconstitucional da tirania segundo a experiência ateniense no séc. VI a.C.: "Então, nós encontramos em Ésquilo, Agamêmnon 1355, 1365, 1633 as palavras tyrannos e tyrannis usadas para designar o regime ilícito instituído depois da morte do legítimo rei Agamêmnon. Talvez seja por isso que os termos tyrannos e tyrannis em Prometeu Acorrentado se aglomeram em torno de Zeus (10, 222, 224, 305, 310, 357, 736, 756, 761, 909, 942, 957, 996), a quem é dado o título de 'tirano' no sentido em que usamos hoje a palavra”. Sobre o Prometeu Acorrentado de Ésquilo, Parker 1998: 159 diz o seguinte: "as declarações de Prometeu [...] certamente ganham sentido se concedemos o uso da palavra tyrannis não no sentido ostensivo de 'realeza', mas no sentido secundário de "poder despótico obtido ilegalmente, i.e. tirania'”. A ideia geral defendida por Parker 1998: 161 em relação aos autores que precedem Tucídides é a de que "dentre todas as palavras para designar o rei, tyrannos é a que mais facilmente se presta a uma interpretação negativa”. Sobre o sentido negativo de tyrannos na tragédia ática, ver também Fisher 1992: 331-332.

18 Sobre a inveja do tirano, ver também Platão, República IX 579b-c.

19 Em seu estudo exaustivo sobre a noção de bybris na literatura e filosofia gregas, de Homero a Aristóteles, N. R. E. Fisher contesta a visão tradicional, que restringe o uso do termo ao âmbito religioso, e propõe uma definição genérica baseada, sobretudo, nas noções de honra e vergonha: "bybris é, essencialmente, o grave ataque à honra de outrem, que provavelmente causa vergonha e conduz à ira e a tentativas de vingança. Hybris é frequentemente, mas não necessariamente, um ato de violência; ela é, essencialmente, uma atividade deliberada, e o motivo típico para tal inflicção de desonra é antes o prazer de expressar um sentido de superioridade do que compulsão, necessidade e desejo por riqueza" (Fisher 1992: 1). As definições tanto de Carey quanto de Fisher concordam tanto no escopo amplo da noção de bybris, que transcende a esfera religiosa, quanto no sentido pejorativo inerente ao termo; no entanto, a de Carey parece preferível para os propósitos deste capítulo, na medida em que, especificamente no episódio de Heródoto que estamos analisando, a prosperidade material está diretamente associada à bybris do governante. 
termo-chave, Heródoto alude aqui ao cerne do problema discutido neste capítulo: é o poder absoluto que engendra a bybris, ou, inversamente, é a bybris que engendra o tirano? A posição que aparece na boca de Otanes aponta para a primeira ordem dessa relação causal por meio de uma reflexão sobre a própria natureza do poder político: até mesmo o melhor dos homens poderia ser corrompido uma vez em posse de um poder ilimitado, passando a agir fora de seu juízo habitual. Nesse sentido, a descrição psicológica, por assim dizer, do indivíduo tirânico, que age com bybris e é acometido pela inveja, deriva de um fato anterior e mais importante, que é o acesso a um poder absoluto irrestrito, visto aqui como causa do desvirtuamento de seu caráter. E esse processo degenerativo é marcado pela mudança do termo mounarchos para tyrannos para qualificar o governante autocrata que incide em bybris, como mencionado acima.

(iii) Em terceiro lugar, o discurso de Otanes possui um traço característico comum a outros autores dos sécs. V e IV a.C.: a saber, uma tendência descritiva no processo de delimitação da figura do tirano e do regime tirânico, em oposição a outros modelos de governante e de regime político ${ }^{20}$. Em outras palavras, trata-se de um procedimento indutivo que parte da enumeração de atos particulares para a generalização de um certo tipo de indivíduo que poderíamos denominar tirano: ou seja, o tirano é um indivíduo tal que comete atos de uma certa qualidade, tais como: "adulterar os costumes dos antepassados, violentar as mulheres e condenar pessoas à morte sem julgamento prévio" (3. 80. 5). Nessas seções descritivas, podemos observar, em linhas gerais, que tanto Heródoto quanto os demais autores não se referem aos possíveis fatores de ordem psicológica que condicionariam um comportamento de tal tipo, limitando-se antes a descrever certas ações particulares características do indivíduo tirânico. Esse mesmo traço aparece também em um dos episódios mais importantes para os estudos sobre a tirania na obra de Heródoto, que é o discurso do coríntio Socles contra a proposta dos lacedemônios de reconduzirem Hípias a Atenas na condição de tirano (5. 90-93) depois da expulsão dos Pisistrátidas empreendida pelos atenienses em 506 a.C. (5. 77-81). Como podemos constatar no proêmio do

20 Ver, por exemplo, Platão, Górgias 471a-d (história de Arquelau, tirano da Macedônia). 
discurso de Socles, os termos tyrannos e tyrannis são usados de modo marcadamente pejorativo, mais próximos à noção geral de tirania desenvolvida no pensamento político grego do séc. IV a.C.:

Por certo o céu passará a estar debaixo da terra, a terra elevar-se-á acima do céu, os homens viverão no mar e os peixes onde antes viviam os homens, no dia em que vocês, Lacedemônios, destituído o regime de igualdade [isokratia], prepararem a instauração da tirania nas cidades [tyrannis] - pois nenhuma das realizações humanas é mais injusta e sanguinária do que este regime. (5.92.1.1)

Durante a narração da experiência de Corinto nas mãos dos tiranos Cípselo (655-625 a.C.) e Periandro (625-587 a.C.) a fim de persuadir os lacedemônios do risco para toda a Hélade de fomentar regimes dessa natureza, Socles caracteriza da seguinte forma o que seria o perfil do governante tirânico:

Vejamos o tipo de governante [tyranneusas] que foi Cípselo! A muitos Coríntios perseguiu-os, a outros tantos usurpou-lhes os bens e a uns quantos mais tirou-lhes a vida. Depois de ter governado durante trinta anos e de ter levado uma vida feliz, sucedeu-lhe à frente do regime tirânico [tyrannis] o seu filho Periandro. Embora de início fosse mais benevolente do que o pai, depois que se associou, por meio de mensageiros, a Trasibulo, tirano de Mileto [tyrannos], tornou-se muito mais sanguinário do que Cípselo. (5. 92. 5. 2-6. 1)

Na sequência da narração, Socles passa a descrever sumariamente as ações iníquas de Periandro influenciadas pelo conselho de Trasibulo, como perseguir e matar os indivíduos mais distintos de Corinto que Cípselo havia poupado durante seu governo, concluindo assim a empresa do pai (5. 92. 7. 1). Depois, ele passa a narrar um episódio envolvendo a sua esposa já morta Melissa, com cujo cadáver havia mantido relações sexuais (5. 92. 7. 3): para descobrir o local onde um depósito havia sido feito por um hóspede seu, o oráculo dos mortos lhe propôs um enigma cuja resolução implicaria 
a revelação almejada pelo tirano. Tendo entendido a mensagem oracular, Periandro agiu da seguinte maneira, segundo a narração de Socles:

Imediatamente depois dessa revelação, o tirano ordenou que todas as mulheres de Corinto se dirigissem ao templo de Hera. Então elas arranjaram-se com os seus mais belos adereços, como se fossem para uma festa. Porém Periandro, que em segredo colocara guardas no local, fez com que todas, sem exceção - tanto as mulheres livres como as de condição servil - se despissem. Colocadas as vestes numa vala, queimou-as, ao mesmo tempo que dirigia uma prece a Melissa. [...] Aqui têm o perfil da tirania [tyrannis], Lacedemônios, e dos atos que a caracterizam. [5. 92. 3-4; meus itálicos]

Portanto, a ênfase do discurso de Socles a fim de dissuadir os lacedemônios de seu propósito de reinstaurar a tirania em Atenas se baseia fundamentalmente na descrição de atos iníquos praticados pelos tiranos de Corinto no séc. VII a.C., sem apelar, todavia, a fatores de ordem psicológica que condicionariam tal tipo de conduta. Nesse sentido, os próprios termos da conclusão da narração de Socles ("aqui têm o perfil da tirania, Lacedemônios, e dos atos que a caracterizam", 5. 92. 7. 4) dão suporte à generalização que estou pretendendo aqui: i.e. a natureza da tirania, e por conseguinte, a do indivíduo tirânico, são delimitadas na obra de Heródoto antes pela descrição de ações particulares de uma certa qualidade que caracterizariam de modo distintivo um indivíduo de tal tipo do que pelo esforço de definir teoricamente o regime tirânico em oposição a outras formas de constituição política ${ }^{21}$. Ou seja, é pela enumeração de atos particulares - tais como perseguir e assassinar cidadãos distintos, confiscar-lhes os bens, violentar as mulheres, alterar os costumes dos antepassados, condenar à morte indivíduos sem julgamento prévio, e assim por diante - que se caracteriza a figura do indivíduo tirânico no exercício do poder autocrático. Essa restrição (i.e. no exercício do poder autocrático) é muito importante para minha análise porque, como vimos no discurso de Otanes, Heródoto trata do problema do indivíduo tirânico enfatizando antes o aspecto político do que as condições

21 Raaflaub 2002: 161, 173. 
psicológicas que possibilitariam tal tipo de comportamento designado genericamente de hybris. Em suma, nesse recorte da obra do historiador proposto aqui, é a tirania que engendra a hybris, e não contrário ${ }^{22}$. Vejamos agora como esse mesmo problema aparece no Édipo Rei, de Sófocles.

\section{3 - Sófocles}

Como mencionado no início deste capítulo, o célebre verso 873 do segundo estásimo do OR de Sófocles (vv. 863-910) tem sido motivo de controvérsia entre os estudiosos da peça desde o final do séc. XIX. A lição unânime dos manuscritos de primeira e segunda ordem é a seguinte: (a)

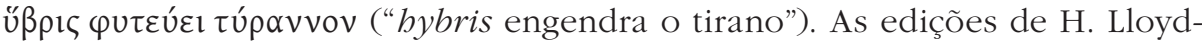
Jones e N. G. Wilson (1992) e de A. Dain e P. Mazon (1958) imprimem a versão original sem emendas, ao passo que a de Dawe (1975 e 1982/2006) opta por uma alteração abrupta do texto a partir da proposta de Blaydes

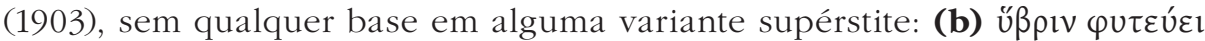

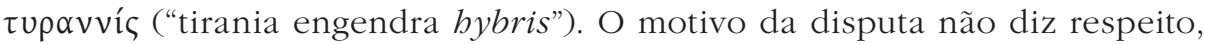
portanto, a problemas de transmissão do texto, tampouco a questões métricas; trata-se exclusivamente de uma polêmica de natureza exegética. O que está em jogo aqui é a ordem da relação causal entre os dois termos-chave da reflexão sobre a genealogia do poder autocrático: afinal, (a) é a bybris que dá origem ao tirano, ou (b) é a tirania que dá origem à bybris? Para compreendermos as razões de tal controvérsia, duas clarificações preliminares são necessárias: (i) primeiro, um breve resumo do contexto da peça em que tal verso aparece na voz do coro, formado por anciãos de Tebas; e (ii) segundo, um comentário sobre a semântica dos termos tyrannos e tyrannis em Sófocles.

(i) Quando o coro dá início ao segundo estásimo, Édipo ainda não tinha chegado à conclusão definitiva de que ele próprio era o assassino de Laio. Mas a menção de Jocasta ao local do assassinato no episódio anterior (i.e trifurcação das estradas que levam a Tebas, Delfos e Dáulia), que coincidia com o lugar

22 Ver também Fisher 1992: 348. 
onde Édipo havia matado um grupo de pessoas, passou a perturbá-lo, pois lhe indicava a possibilidade de se tratar de um único e mesmo evento. Até então, havia aparentemente dois homicídios ocorridos separadamente (v. 730, 800): o assassinato de um grupo de viajantes cometido por Édipo depois de ter sido insultado e agredido, e o assassinato de Laio e sua comitiva, da qual restou apenas um sobrevivente, que permanecia fora da cidade desde o crime (v. 761). Jocasta, por sua vez, se mantém convicta de que são dois assassinatos independentes, ao passo que o coro, embora mostre preocupação com a coincidência então revelada, mantém-se ao lado de Édipo, sugerindo-lhe de maneira prudente que esperasse a chegada da testemunha ocular sobrevivente para confirmar se se tratava de um bando de criminosos que matara Laio (pois essa era a versão corrente), ou se de um único indivíduo. Caso a versão corrente fosse corrigida pela testemunha ocular (i.e. do plural para o singular), então Édipo teria a confirmação de que ele era de fato o assassino de Laio, o que lhe implicaria sofrer as sanções que ele próprio havia proclamado contra quem estava maculando Tebas. É nesse momento de tensão, portanto, que se inicia o segundo estásimo da peça que discutiremos a seguir.

(ii) A semântica dos termos-chave tyrannos e tyrannis, por sua vez, é uma questão problemática, tal como sucede no caso da obra de Heródoto. Especificamente no caso de Sófocles, todas as ocorrências dos termos tyrannos e tyrannis em sua obra, segundo o Lexicon Sophocleum (Ellendt 1986), têm uma conotação neutra de "rei", "soberano", "monarca", com uma única exceção em que tyrannos teria sido empregado negativamente: OR v. $873^{23}$. Isso parece ser incontestável a partir da lição unânime dos manuscritos (a), porque tyrannos aparece aqui como fruto da bybris, o que, como foi dito acima, tem um valor intrinsecamente pejorativo ${ }^{24}$. Nas demais ocorrências dos termos na peça, o sentido é sempre de "rei" e "realeza"25.

23 Fisher sugere outras três passagens da Antígona de Sófocles em que tyrannos é empregado claramente em sentido pejorativo: v. 506-ss, 1056, 1169.

24 Fisher 1992: 332: "é a própria hybris que cria aqui o contexto que assegura o sentido pejorativo de tyrannon”. Brandenburg 2005: 34, por seu turno, defende a tese contrária.

25 Sófocles, Édipo Rei v. 514, 588, 799, 925, 939, 1043, 1095 (tyrannos); v. 380, 535, 541, 592 (tyrannis); v. 408 (tyranneo). 
Portanto, tendo em vista essa peculiaridade do verso 873 no interior da obra supérstite de Sófocles, Dawe (1975, 1982/2006) opta por adotar a proposta radical de Blaydes de alteração do texto (b) com base em dois $\operatorname{argumentos}^{26}$ : (a) a ideia de que o poder absoluto corrompe o indivíduo ("a tirania engendra bybris") é um lugar-comum do pensamento político grego, como vimos há pouco no Debate Constitucional na Corte Persa em Heródoto $(3.80)^{27}$; nessa versão modificada, tyrannis não teria uma conotação necessariamente negativa; e (b) a ideia de que a "bybris engendra o tirano", por outro lado, não teria qualquer valor para o caso de Édipo, visto que ele obteve o poder em Tebas como uma dádiva não solicitada por ele (cf. v. 384), e não por uma conduta que se caracterizaria como bybris, além de ser representado na peça como um soberano que zela pelo bem de sua comunidade, a quem o sacerdote se volta no início da peça como alguém especialmente favorecido pelo deus (v. 38). Por essas duas razões, a leitura do texto legado unanimemente pelos manuscritos não seria plausível, daí a necessidade de uma correção no texto, como havia proposto Blaydes (1903). Como fica evidente, a interpretação de Dawe do segundo estásimo da peça parte do princípio de que essa máxima da primeira antístrofe tem como referente especificamente Édipo; e, assumindo isso, seria de fato estranho um canto coral de teor admoestativo, quando até então o coro vinha se mantendo sempre ao lado de Édipo ${ }^{28}$.

26 Dawe 2006, pp. 147-148.

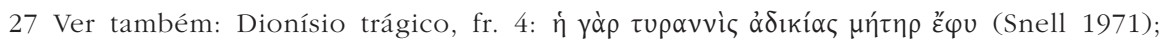

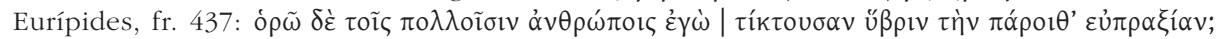

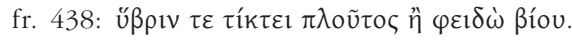

28 Kamerbeek (1967: 172) entende que o referente aqui é Édipo em particular, sem todavia se apoiar na emenda de Blaydes: "O que o Coro teme pode ser descrito assim: se Édipo devesse ser realmente o assassino de Laio, e seguir Jocasta em sua descrença nos oráculos, então as leis divinas não-escritas deixariam de controlar seu governo e, por conseguinte, a própria polis. Sua hybris se desenvolveria em tirania; ausência de leis e irreligião reinariam. Ele não se preocuparia em obedecer à ordem de Apolo de punir o assassino de Laio, e a cidade se encaminharia à ruína" (meus itálicos). Knox, por sua vez, apoiando-se na sua tese do espelhamento entre Édipo e Atenas (polis tyrannos), defende também que o canto é direcionado a Édipo: "O estásimo é uma avaliação da origem, natureza e queda inevitável do tyrannos; quando o coro canta suas linhas solenes de abertura, a semelhança entre Édipo e Atenas já está clara e firmemente estabelecida, de modo que o poeta possa falar de ambos como se fossem um só. Quando o coro passa de um apelo às leis humanas para a justiça de um tribunal supremo, o Édipo tyrannos e a tyrannis ateniense estão tão intimamente associados na mente e na linguagem do poeta que ele pode atribuir a Édipo falhas que não são encontradas no herói da peça, mas nas ações da cidade da qual ele é 
Todavia, há outras maneiras de interpretar o valor dessa máxima (“bybris engendra o tirano"): ou (i) como uma asserção universal (gnome), como uma reflexão genérica sobre os limites e as consequências da bybris que um indivíduo, quem quer que ele seja, pode cometer, e não especificamente Édipo (Carey 1986; Fisher 1992); ou (ii) como uma referência do coro à hipótese da conspiração aventada por Édipo ao longo da peça, segundo a qual Creonte e Tirésias estariam agindo em conluio com os supostos assassinos de Laio a fim de usurparem o poder de Tebas (Brandenburg 2005); nesse segundo caso, a admoestação do coro estaria direcionada aos supostos conspiradores, e não a Édipo. Ambas as interpretações alternativas à de Dawe possuem a enorme vantagem de manter intacta a lição dos manuscritos, buscando resolver o suposto problema exegeticamente. Para os propósitos deste capítulo, explorarei então essa segunda via de leitura mantendo o texto legado pelos manuscritos (a), sem a necessidade de determinar, a princípio, o referente do canto coral (i.e. (i) sujeito indeterminado ou (ii) grupo de conspiradores). Pois o ponto relevante aqui é precisamente a genealogia do tirano que apenas a lição dos manuscritos nos permite explorar: ou seja, é um determinado tipo de comportamento, designado genericamente de hybris, que gera o indivíduo tirânico ${ }^{29}$. Como vimos na discussão sobre Heródoto, a crítica de Otanes à monarquia/tirania se baseia no argumento de que é o poder absoluto que proporciona as condições para que o governante incida em bybris, invertendo assim a ordem dos fatores nessa relação causal bybris/tirania que vemos referida no verso 873 do OR. A proposta de Blaydes adotada por Dawe (b) reduziria, portanto, a máxima de Sófocles a esse lugar-comum do pensamento político (i.e. "a tirania engendra bybris), quando, na verdade, o poeta está apontando para um outro viés de reflexão sobre o poder autocrático: um deslocamento do

o símbolo dramático" (2002: 88). No entanto, mesmo a leitura de Knox ainda evidencia a discrepância entre a caracterização de Édipo na peça e a descrição da figura do tyrannos no segundo estásimo, cuja tentativa de resolução se deve à assunção (controversa, para dizer o mínimo) de que as características não reportáveis a Édipo seriam reportáveis à cidade de Atenas de modo complementar.

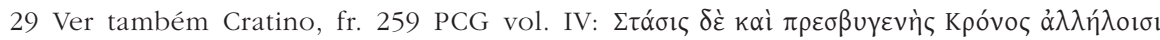

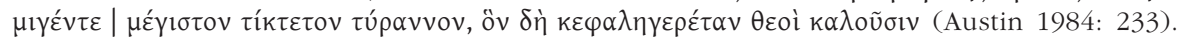


enfoque no poder político para a própria constituição do indivíduo tirânico (i.e. "bybris engendra o tirano").

Vejamos, então, como a análise do segundo estásimo não apenas confirma que a lição dos manuscritos do verso 873 está correta, como também indica que o mote do canto coral consiste justamente no problema envolvido na genealogia do tirano e suas consequências funestas para a cidade. Comecemos com um breve resumo da primeira estrofe (v. 863-872), que não entra no escopo desta análise: nela, o coro roga à Moira ("destino") para que o auxilie em sua reverência piedosa, tanto nos atos quanto nas palavras, em observância às leis sempiternas estabelecidas pelo Olimpo. Essa prece se justifica pelo que é dito na segunda antístrofe (v. 896-910), quando o coro expressa o temor de que as leis divinas já não mais possuíssem qualquer valor, uma vez que as profecias de Apolo não haviam aparentemente se consumado (até este momento do drama, Jocasta está convicta de que a criança havia sido morta, e que Laio havia sido assassinado por um bando de criminosos, o que contradizia o destino de Laio e Édipo profetizado por Apolo). O coro, portanto, compartilha por ora dessa versão, que logo cairá por terra, e teme justamente uma atitude irreverente para com os costumes religiosos por conta disso, como o desdém à palavra oracular expresso pela própria Jocasta, no terceiro episódio que antecede a esse estásimo (v. 707725). Pois bem, depois da prece do coro, inicia-se então a primeira antístrofe com o célebre verso referido acima:

Hybris engendra o tirano. Se em vão

bybris se abarrota de tudo quanto

não é oportuno nem proveitoso,

ao assomar às mais altas ameias

se apressa rumo ao precipício inevitável,

onde calcar o pé não lhe é

de serventia. A pugna profícua

à cidade, rogo a deus que jamais

a extinga.

Da proteção do deus jamais abdicarei. (v. 873-882) 


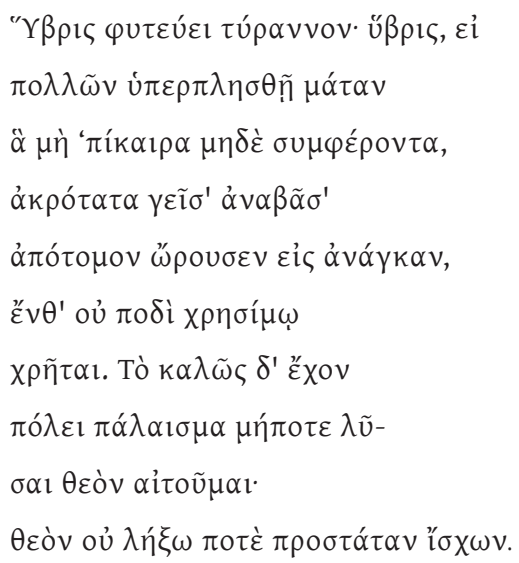

A primeira parte da antístrofe (v. 873-879) aborda de maneira convencional a ascensão e queda da bybris humana, que aparece aqui personificada e não referida a um indivíduo específico, o que corrobora a natureza generalizante de tal reflexão (pro Carey 1986). A esse quadro vem contraposta "a pugna profícua à cidade" (v. 880-881), que é interpretada de diferentes maneiras pela crítica contemporânea: (i) a luta de Édipo para encontrar o assassino de Laio e purificar a cidade (Kamerbeek 1967: 177); (ii) a luta mais ampla travada por Édipo durante o seu reinado em Tebas (WinningtonIngram 1971: 125); (iii) a competição construtiva entre os cidadãos que sucede em qualquer sociedade ordenada e estável, seja numa democracia, seja numa oligarquia, seja em Tebas sob o comando de Édipo (Carey 1986: 177; Fisher 1992: 333-335; aparentemente Dawe 2006: 149); ou (iv) a luta do próprio deus para beneficiar a cidade e mantê-la afastada do tyrannos (Brandenburg 2005: 34). Independentemente de qual seja a versão mais plausível (se é que há uma versão mais plausível nesse caso), o ponto essencial aqui é que, nessa primeira antístrofe, vem claramente contraposta a bybris desmedida que gera o indivíduo tirânico ${ }^{30}$ à competição benéfica interna à cidade, cuja preservação o coro roga a deus ${ }^{31}$.

30 Observe a ideia de "desmedida" e "excesso" salientada pelo prefixo byper na forma verbal ú $\varepsilon \varepsilon \rho \pi \lambda \eta \sigma \theta \tilde{n}$ (v. 874): não se trata simplesmente de "satisfazer-se" ou "fartar-se", mas "satisfazer-se" ou "fartar-se" em excesso. Por essa razão, optei aqui pela tradução "abarrotarse".

31 Bollack 1990: 565: "Sem procurar uma tomada de posição seja do coro em favor de Édipo, seja de Sófocles, por meio do coro, contra a ameaça de uma facção, a expressão, 
De todo modo, a parte mais relevante do segundo estásimo para os propósitos deste capítulo consiste na segunda estrofe (v. 883-896), quando o coro passa a descrever os tipos de ação que caracterizariam o comportamento ultrajante de um indivíduo ( $\tau \iota \varsigma$, v. 883) que incorre em bybris. Vejamos primeiramente os versos 883-891:

Porém, se alguém, nas palavras

ou nos atos, procede arrogante,

sem temer a justiça, sem

venerar as sedes dos deuses,

que um destino funesto o acometa

por conta de sua malfadada insolência,

caso não obtenha lucro de modo justo

e não se abstenha de atos ímpios,

ou caso viole, insensato, o inviolável.

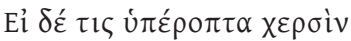

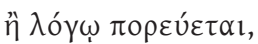

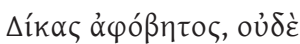

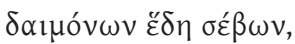

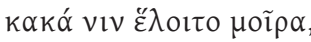

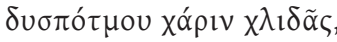

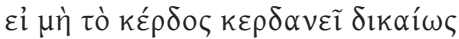

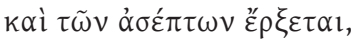

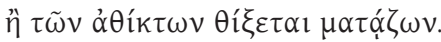

O vocabulário empregado aqui salienta em especial dois vícios do indivíduo que age com bybris - i.e., impiedade e injustiça - que se manifestam tanto em suas ações quanto em suas palavras (v. 883-884). Os

em um nível mais especulativo, fornece, dentro da tensão que a anima, uma definição da vida política mais geral (ver Campbell: "é inútil supor alguma referência particular ou alusão nessas palavras, as quais simplesmente denotam a luta de um zelo patriótico como distinto dos conflitos provenientes de uma ambição desregrada"). A vida das cidades repousa, em primeiro lugar, sobre uma rivalidade entre vontades particulares; a luta pelo poder é nela mesma um movimento desordenado, mas se torna benéfico à comunidade se os interesses são mantidos em equilíbrio por um sistema regulatório". 
versos 883-891 compartilham da mesma característica que observei anteriormente em relação ao tratamento da tirania em diferentes textos do séc. V e IV a.C. (Heródoto, Tucídides, Platão): a saber, a tendência de descrever certos tipos de ação que caracterizariam distintivamente o indivíduo tirânico (nesse caso aqui, arrogância nas ações e nas palavras, desrespeitar as sedes dos deuses, lucrar injustamente, tocar em coisas intocáveis) ${ }^{32}$. No entanto, encontramos nessa mesma passagem uma qualificação suplementar que salienta exatamente aquilo que venho procurando divisar no exame de certas obras supérstites do séc. V a.C.: a saber, um elemento psicológico que esteja associado às motivações do tirano. E nessa segunda estrofe, o coro qualifica tal indivíduo como alguém não temeroso à justiça (v. 885). Se por "justiça" Sófocles se refere aqui às punições infligidas pelos homens a quem comete injustiças, então a conduta de um indivíduo que age com bybris (como, por ex. obter vantagens de modo injusto, cf. v. 889) pode ser explicada, até certo ponto, por um fator de ordem psicológica: ele age de tal modo por não ser refreado pelo medo de ser punido. Por essa razão, o coro roga que um "destino funesto" (v. 888) se apodere desse indivíduo, ou seja, que ele seja punido pelos deuses, uma que vez que suas ações infringem tanto as leis instituídas pelos homens quanto os costumes religiosos ${ }^{33}$.

Esse elemento psicológico trazido à baila por Sófocles torna mais complexo, portanto, o problema envolvido na genealogia do tirano, na medida em que ele aponta para fatores internos ao agente que condicionariam, até certo ponto, suas ações externas (descritas em profusão pela literatura que aborda por diferentes vieses o problema da tirania). Por conseguinte, o problema da tirania transcenderia, nessa perspectiva, a esfera política, e

32 Fisher 1992: 337 identifica referências semelhantes a esses atos típicos de bybris em Sólon e Ésquilo: desrespeitar as sedes dos deuses (cf. Sólon, 4.13-4; Ésquilo, Agamêmnon 380-ss., 773-ss.; Eumênides 511-ss., 538-ss.); lucrar injustamente (cf. Sólon, 4.11-ss, 13.7-ss.; Ésquilo, Agamêmnon 376-ss.; Eumênides 540-541); tocar em coisas intocáveis (cf. Ésquilo, Agamêmnon 370-371).

33 Brandenburg (2005: 36) interpreta de modo diferente esses versos, entendendo que dikas (v. 885) corresponde a nomoi (v. 865). Nesse caso, não haveria a distinção que estou

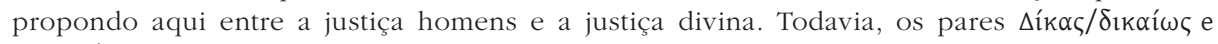

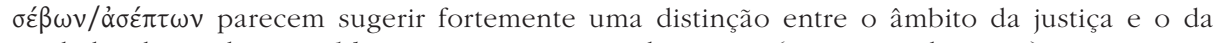
piedade, de modo que dike teria aqui um sentido estrito (i.e. justiça humana). 
passaria a compreender fatores psicológicos que estariam na própria constituição do indivíduo tirânico.

Mas a não suscetibilidade ao medo não é o único elemento de ordem psicológica que aparece salientado nessa segunda estrofe. Nos versos restantes, o coro diz o seguinte:

Que homem, imerso nisso, ainda conseguiria manter a alma incólume às hastas do thymos?

Pois se tais atos são honrosos, por que devo continuar a dançar? (v. 892-896)

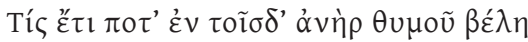

$\tau \varepsilon u ́ \xi \varepsilon \tau \alpha l ~ \psi v x \tilde{\alpha} \varsigma \alpha \dot{\alpha} \mu v ́ v \omega v ;$

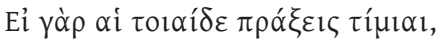

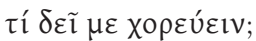

Há vários problemas de natureza filológica envolvidos no estabelecimento do texto dessa passagem, nos quais não poderei me deter aqui. Mas o ponto mais relevante que interessa diretamente ao tema deste capítulo é como compreender o sentido de thymos ("hastas do thymos", v. 892). O campo semântico do termo é bastante complexo, podendo designar em Sófocles, segundo Ellendt 1986, "a alma como um todo", "alma cheia de ardor", "ira", "indignação", "mente". No caso específico dessa passagem, os tradutores e estudiosos da peça se dividem basicamente em duas vertentes principais: (a) a que segue a leitura dos escólios ${ }^{34}$, que sugerem que "hastas do thymos" designariam aqui a punição e justiça divinas provenientes da fúria do deus perante as iniquidades cometidas pelo indivíduo que age com bybris (portanto, como algo externo ao agente) (Alamillo 1981, Dawe 2006, Vieira 2001) ${ }^{35}$; e (b) a que propõe como tradução "hastas da paixão" (Brandenburg 2005, Lloyd-Jones \& Wilson 1992), ou mais especificamente, "hastas da

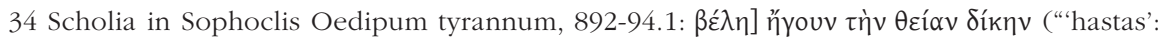
referiam-se à justiça divina").

35 Dawe 2006: 150, embora não adote na edição do texto a emenda de Hermann (i.e. $\theta \varepsilon \tilde{\omega} \vee \beta \varepsilon ́ \lambda \eta$, "hastas dos deuses"), admite que ela captaria melhor o sentido pretendido por Sófocles. Fisher (1992: 337), por sua vez, acata tal emenda. 
cólera" (Dain \& Mazon 1968) (portanto, como algo interno ao agente) ${ }^{36}$. Ambas as alternativas são factíveis do ponto de vista exegético, pois o contexto do canto coral contrapõe o domínio divino ao individual. É evidente que, se meu intuito é buscar divisar os elementos de ordem psicológica que condicionariam a formação do indivíduo tirânico, a alternativa (b) se apresenta como uma leitura muito mais profícua. Se, então, entendermos a expressão "hastas do thymos" como algo que aflige internamente o agente, e não uma punição que o acomete externamente, então temos aqui uma reflexão que aponta para uma determinada constituição psicológica em que o thymos aparece como o elemento proeminente: a alma de um indivíduo acometido por bybris, que dá origem ao tirano, é afligida continuamente pelo thymos; em outras palavras, o thymos constitui a fonte suprema de motivação.

A dificuldade decorrente disso, no entanto, é precisar o sentido de thymos pretendido por Sófocles aqui, no caso de entendê-lo como algo interno ao agente: "ira"? Ou mais genericamente "sede das paixões", sendo o thymos a fonte de impulsos de diversas espécies, que, na perspectiva platônicoaristotélica, seriam definidos como irracionais, sobre os quais o agente acometido por bybris não teria domínio, levando-o assim a cometer atos iníquos? Seria muito difícil, senão impossível, delimitar de modo seguro o campo semântico de thymos neste verso sofocliano. Todavia, essa imprecisão não compromete a conclusão geral pretendida neste capítulo: ou seja, observar que, no segundo estásimo do OR, Sófocles aborda o problema da genealogia do tirano salientando fatores de ordem psicológica (destemor, thymos) que condicionariam seu comportamento irreverente e desregrado, transcendendo assim o lugar-comum do pensamento político grego, que se limitava à descrição das ações externas do indivíduo tirânico que o caracterizariam como tal, como vimos na análise das passagens da obra de Heródoto $^{37}$.

36 Sobre o retrospecto histórico das diferentes leituras e das diversas propostas de emenda do texto, ver Bollack 1990: 572-581.

37 Nesse sentido, o segundo estásimo do OR de Sófocles poderia ser visto como uma instância em que a tragédia se insere no ambiente mais amplo de discussão teórica sobre o pensamento democrático, como ressalta Goldhill 2000: 74: "Da mesma maneira em que a estrutura institucional do teatro antigo pode ser visto como político em um sentido completo 


\section{4 - CONCLUSÃO}

A reflexão sobre a gênese do tirano está intimamente associada ao pensamento político sobre a democracia, tal como desenvolvido em Atenas nos sécs. V e IV a.C. A tirania constitui a negação do princípio democrático que está na base de sua constituição: to ison, a igualdade entre os cidadãos. Portanto, refletir sobre a tirania é pensar nos limites da própria democracia, no germe de sua dissolução. Embora Heródoto proviesse de Halicarnasso, cidade da Cária (costa ocidental da atual Turquia), ele passou parte de sua vida em Atenas, embora seja difícil precisar em que condições e por quanto tempo isso se deu. De todo modo, sua experiência em uma cidade democrática, bem como sua inserção no ambiente intelectual de Atenas na segunda metade do séc. V. a.C., influenciaram seguramente suas reflexões sobre a natureza do poder autocrático e o caráter do governante autocrata, motivo que aparece disperso por toda a sua obra. Nesse sentido, o Debate Constitucional na Corte Persa, embora não seja encenado em Atenas, possui as características peculiares de um tipo de discussão empreendida em um ambiente democrático, e traz em si os fundamentos da reflexão a respeito dos diferentes regimes políticos, que será ampliada e aprimorada, de diferentes maneiras, por autores do séc. IV, tais como Platão, Isócrates, Xenofonte e Aristóteles ${ }^{38}$.

No caso da tragédia, e, em especial, do Édipo Rei de Sófocles, esse pensamento de caráter universalizante sobre a tirania e o tirano, como vimos na análise do segundo estásimo da peça, reflete justamente o tipo de discussão ético-política empreendida em Atenas naquela época. Como considera Knox: "A referência contemporânea em toda a tragédia ática é tão óbvia e insistente que o termo 'anacronismo', em geral aplicado a

e convincente, assim também a sua escrita é completa e intrincadamente política desde referências específicas a questões contemporâneas às mais amplas abstrações do pensamento democrático" (meus itálicos).

38 Sobre o tema, ver Evan 1981. 
detalhes da apresentação trágica do material mítico, é completamente falacioso; na tragédia ática do séc. V, o anacronismo não é a exceção, e sim a regra"39. Dessa forma, quando lemos a peça sob o viés do pensamento político ateniense do séc. V a.C., podemos observar como a tirania é concebida ali não apenas como um problema de ordem política, mas também (e, talvez, prioritariamente) de natureza psicológica; ou seja, a tirania tem como base a formação de um tipo determinado de indivíduo, com certas motivações e afecções, que encontra na política os meios ideais para dar vazão a seus desejos e satisfazer seus interesses privados em detrimento do bem comum. Quando isso se concretiza no interior de uma cidade democrática, a democracia encontra seu fim.

\section{BIBLIOGRAFIA}

Alamillo, A. (1981), Sófocles: Tragedias, introducción de J. Vega. Madrid.

Austin, C. (1984), "Oedipus Tyrannus 873", CQ 34. 1: 233.

Asheri, D.; Lloyd, A. \& Corcella, A. (2007), A Commentary on Herodotus Books I-IV. Oxford.

Bollack, J. (1990), L'Oedipe Roi de Sophocle. Lille.

Brandenburg, P. (2005), "The Second Stasimon in Sophocles' Oedipus Tyrannus", AC 74: 29-40.

Carey, C. (1986), “The Second Stasimon of Sophocles' Oedipus Tyrannus", JHS 106: 175-79.

Dain, A. \& Mazon, P. (1968), Sophocle, vol. 2. Paris.

Dawe, R. D. (1975), Sophoclis Tragoediai, Tom. I. Leipzig. (2006), Sophocles. Oedipus Rex. Cambridge.

Dewald, C. (2003), "Form and Content: The Question of Tyranny in Herodotus", in K. Morgan (ed.), Popular Tyranny. Austin, 25-58.

. (2007), "Tyranny in Herodotus", in R. B. Strassler (ed.), The Landmark Herodotus. New York, 835-38.

Ellendt, F. (1986), Lexicon Sophocleum. Hildesheim.

Evan, J. A. S. (1981), "Notes on the Debate of the Persian Grandees in Herodotus 3,80-82", QUCC, N. S. 7: 79-84.

Fisher, N. R. E. (1992), Hybris: a Study in the Values of Honour and Shame in Ancient Greece. Warminster.

Giorgini, G. (2005), "Il Tiranno", in M. Vegetti (ed.), La Repubblica. Libro VIII-IX. Napoli.

Goldhill, S. (2000), "Greek Drama and Political Theory", in C. Rowe \& M. Schofield (eds.), The Cambridge History of Greek and Roman Political Thought. Cambridge, 60-88.

Kamerbeek, J. C. (1967), The Plays of Sophocles. Part IV: The Oedipus Tyrannus. Leiden. Silva, M. F. \& Abranches, C. (1997), Heródoto: Histórias, Livro III. Lisboa.

39 Knox 2002: 51 . 
Silva, M. F. \& Soares, C. L. (2007), Heródoto: Histórias, Livro V. Lisboa.

Knox, B. (2002), Édipo em Tebas, trad. Margarida Goldsztyn. São Paulo.

Lloyd-Jones, H. \& Wilson, N. G (1990), Sophoclea. Studies on the Text of Sophocles.

. (1992), Sophoclis Fabulae. Oxford.

Marchant, E. C. (1971), Xenophontis opera omnia. Oxford.

Parker, V. (1998), "Tyrannos. The Semantics of a Political Concept from Archilochus to Aristotle", Hermes 126. 2: 145-72.

Raaflaub, K. A. (2002), "Philosophy, Science, Politics: Herodotus and the Intellectual Trends of his Time", in E. J. Bekker et al. (eds.), Brill's Companion to Herodotus. Leiden, 149-86.

Schofield, M. (2006), Plato. Oxford.

Vieira, T., (2001) Sófocles: Édipo Rei. São Paulo.

Winnington-Ingram, R. P. (1971), "The Second Stasimon of the Oedipus Tyrannus". JHS 91: 119-35. 